\title{
PERAN ORIENTASI PASAR, PROGRAM PROMOSI DAN INOVASI DALAM MENENTUKAN KINERJA PEMASARAN JASA
}

\author{
Retno Dewanti $^{1}$; Henderi Budi Utomo ${ }^{2}$; Andrie Hidayat ${ }^{3}$ \\ 1,2,3 Jurusan Manajemen, Fakultas Ekonomi dan Bisnis, Universitas Bina Nusantara \\ Jln. K.H. Syahdan No. 9, Palmerah, Jakarta Barat 11480 \\ retnodewanti@binus.edu
}

\begin{abstract}
Experience, hard work, and support from the management team and skilled staff have made WOM Finance to be one of the best consumer's financing companies in Indonesia. Therefore, it is important to do an evaluation on the performance of marketing. The method of analysis with the help of statistical regression correlation showed that market orientation significantly has partial influence on improving credit services marketing performance. Promotion program is also has significant partial effect on marketing performance, as well as economic innovation that has successfully influenced marketing performance. However, when market orientation is conducted jointly with the program of economic promotion and innovation it did not bring a positive impact so that in the present moment the emphasis needs to be evaluated on choice of orientation activities.
\end{abstract}

Keywords: orientation, promotion, innovation, marketing, service

\begin{abstract}
ABSTRAK
Pengalaman, kerja keras, serta dukungan tim manajemen dan staf yang handal membawa WOM Finance menjadi salah satu perusahaan pembiayaan konsumen yang terbaik di Indonesia. Untuk itu penting dilakukan evaluasi pada kinerja pemasarannya. Metode analisis dengan bantuan alat statistik korelasi regresi menunjukkan bahwa orientasi pasar secara parsial berpengaruh signifikan meningkatkan kinerja pemasaran jasa kredit. Program promosi secara parsial berpengaruh signifikan terhadap kinerja pemasaran, begitu juga inovasi ekonomi yang telah dilakukan berhasil berpengaruh pada kinerja pemasaran. Namun, bila orientasi pasar dilakukan secara bersama-sama dengan program promosi dan inovasi ekonomi ternyata tidak membawa dampak yang positif sehingga dalam momen sekarang ini perlu untuk dievaluasi penekanan pilihan aktivitas orientasinya.
\end{abstract}

Kata kunci: orientasi, promosi, inovasi, pemasaran, jasa 


\section{PENDAHULUAN}

Perusahaan Leasing di Jakarta saat ini antara lain BAF, ADIRA Finance, Bhakti Finance, OTO Finance, dan WOM Finance. WOM termasuk perusahaan leasing yang memiliki prestasi yang dinamis karena laba yang diperoleh dari tahun ke tahun terus meningkat, seiring dengan bertambahnya jumlah motor di Jakarta. Data dari majalah WOM menunjukkan bahwa setiap tahun terjadi kenaikan rata-rata 5\%. Di tengah persaingan saat ini, pemasaran dirasakan menjadi faktor terpenting bagi perusahaan dalam memasarkan kredit yang ditawarkan. Dalam penyaluran kredit sepeda motor, biasanya kinerja pemasaran lebih ditekankan pada market share relatif, return on investment, dan tingkat pertumbuhan penjualan dari perusahaan tersebut. Kinerja perusahaan dalam perusahaan dapat ditingkatkan dengan melakukan orientasi pasar yang merupakan pemahaman perusahaan terhadap keinginan konsumen sehingga dapat menciptakan nilai superior bagi pelanggan secara continue. Orientasi pasar membantu perusahaan untuk mampu melihat kekuatan, kelemahan baik jangka pendek maupun panjang, kapasitas, dan evaluasi terhadap strategi-strategi yang dilakukan oleh pesaingpesaingnya, dan dapat merespon serta memberikan pelayanan yang lebih baik kepada konsumen mereka di kemudian hari.

Perusahaan juga perlu untuk melakukan program promosi yang merupakan suatu alat komunikasi yang dapat memberikan informasi mengenai produk perusahaan pada masyarakat yang dapat dilakukan melalui personal selling, periklanan, direct marketing, dan sales promotion. Keberhasilan dan pelaksaaan program promosi yang tepat akan berdampak positif dalam memperlancar pemasaran jasa untuk meraih pangsa pasar dalam kelompok jasanya. Dalam menciptakan daya saing di dalam perusahaan perlu adanya inovasi ekonomi, orientasi pasar, dan program promosi yang sesuai dengan sasaran. Peranan inovasi ekonomi sangatlah penting, yakni penerapan satu gagasan dan pemikiran baru dan menawarkan produk baru yang menarik serta meningkatkan pelayanan yang memuaskan pelanggan. Dengan terus melakukan inovasi ekonomi, maka perusahaan dapat memberikan suatu nilai lebih atau mendapatkan keunggulan kompetitif.

Identifikasi masalah pada penelitian ini adalah (1) Apakah orientasi pasar berperan dalam mempengaruhi kinerja pemasaran jasa kredit, 2) Apakah program promosi berperan dalam mempengaruhi kinerja pemasaran jasa kredit, 3) Apakah inovasi ekonomi berperan dalam mempengaruhi kinerja pemasaran jasa kredit, dan 4) Bagaimanakah peranan orientasi pasar, program promosi, dan inovasi ekonomi secara bersama-sama dalam menentukan kinerja pemasaran jasa kredit.

Tujuan yang hendak dicapai dalam penelitian ini adalah untuk mengetahui (1) peranan orientasi pasar dalam mempengaruhi kinerja pemasaran jasa kredit, (2) peranan promosi dalam mempengaruhi kinerja pemasaran jasa kredit, (3) peranan inovasi ekonomi dalam mempengaruhi kinerja pemasaran jasa kredit, dan (4) peranan orientasi pasar, program promosi serta inovasi ekonomi secara bersama-sama dalam menentukan kinerja pemasaran jasa kredit.

\section{Orientasi Pasar}

Pengertian orientasi pasar menurut beberapa ahli adalah sebagai berikut. Menurut Kohli dan Jaworski (1990) serta Narver dan Slater (1990) yang dikutip oleh Pramono dan Waridin (2006:35), menguraikan definisi dari orientasi pasar adalah "Orientasi pasar sebagai kemampuan untuk mencermati kekuatan dan kelemahan pesaing dan strategi-strategi yang dilakukan oleh pesaing dalam suatu orientasi pasar”.

Yang menguraikan bahwa karakteristik kunci orientasi pasar dapat dilihat dari "kemampuan untuk merespon reaksi pelanggan dan memberikan pelayanan yang dapat menciptakan keinginan konsumen untuk membeli suatu produk yang ditawarkan” (Gregorios Chandra, 2002:17). “Orientasi 
membantu pihak manajemen dalam mengidentifikasi kapabilitas unik yang tuntutan nilainya bisa selaras dengan kapabilitas tesebut. Orientasi pasar yang sukses akan mengarah pada kinerja superior. Keberhasilan orientasi pasar ditunjang pula oleh kemampuan mengidentifikasi dan memperluas kapabilitas unik”, yang dapat digambarkan sebagai berikut:

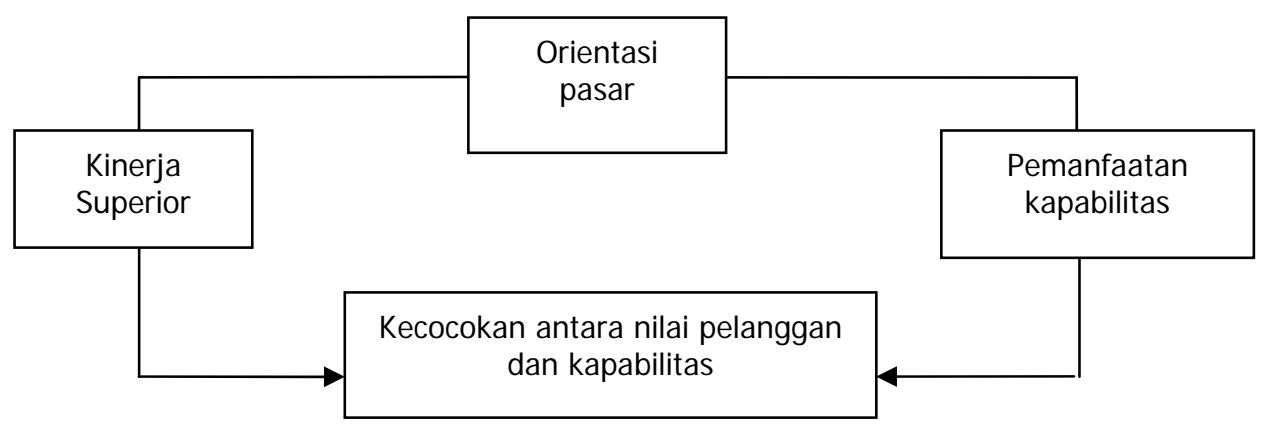

Sumber: Gregorios Chandra (2002:17)

Gambar 1 Karakteristik Orientasi Pasar

Boyd (2004:13) menguraikan definisi dari orientasi pasar, yaitu "A market oriention has significant effeck on various dimensions of performance, including of return on assets, sales growth, and new product success". Sedangkan Kholi dan jaworski (1990:18) menyatakan bahwa "Market orientation as the ability of an organization to generate, dissemimate and use superior information about both custumer and competitor".

\section{Komponen Orientasi Pasar}

Komponen orientasi pasar adalah sebagai berikut. Pertama, orientasi pelanggan. Mengutip pendapat Richard L.Daft (2003:80) mendefinisikan costumer sebagai "People and organization in the environment who can meet the needs and wants of customers both products and services from the organization". Mengutip pendapat Kotler (2003:273) mendeskripsikan bahwa "A costumer centered company focus more on custumers development in formulating its strategis". Kedua, orientasi pesaing. Daft (2003:80) mendefinisikan sebagai berikut "Competitor is other organization in the same industry or type of business. That provides goods or service in the same set custumer". Kotler (2003:273) mendeskripsikan sebagai berikut "Competitor orientation is one whose moves are basically deciated by competitors action and reaction". Ketiga, koodinasi antar fungsi. Mengutip pendapat Liu dan Davies (2000), maka disajkan sebagai berikut "noted that fungsional coordination is a critical factor in retail business".

\section{Promosi}

Promosi merupakan jenis kegiatan pemasaran perusahaan yang ditujukan untuk mendorong permintaan. Semakin gencar kegiatan promosi yang dilakukan perusahaan, maka konsumen akan semakin tertarik dan terpengaruh sehingga akhirnya konsumen akan membeli produk yang dihasilkan dan ditawarkan perusahaan. Program promosi adalah program yang mengacu pada teknik-teknik untuk mengkomunikasikan informasi tentang produk dan menjual produk (Kotler 2002:626). Kegiatan promosi juga sangat bermanfaat untuk perusahaan karena pemasaran menghendaki lebih dari sekedar mengembangkan produk atau jasa dengan baik, menetapkan harga bersaing atau memungkinkan produk atau jasa untuk meraih pangsa pasar dalam kelompok produknya. 
Menurut Harper (2000:65), "promosi adalah suatu program terkendali dan terpadu dari metode komunikasi material perusahaan atau produk yang dapat memuaskan konsumen, mendorong penjualan serta memberi kontribusi pada kinerja laba perusahaan”. Menurut Swastha (2000:245), "Promosi yang baik dapat menjadi tolak ukur perusahaan dalam menciptakan kinerja pemasaran yang maksimal”. Menurut Tjiptono (2002:221), "Promosi adalah suatu bentuk aktivitas pemasaran yang berusaha menyebarkan informasi, memperluas jangkauan, mempengaruhi atau membujuk, dan atau mengingatkan pasar sasaran atas perusahaan dan produknya agar bersedia menerima, membeli, dan loyal pada produk yang ditawarkan perusahaan yang bersangkutan".

Menurut Saladin (2003:123), "promosi adalah suatu komunikasi informal penjual dan pembeli yang bertujuan untuk merubah sikap dan tingkah laku pembeli, yang tadinya tidak mengenal menjadi mengenal sehingga menjadi pembeli dan tetap mengingat produk tersebut”. Menurut Gallo (2005:119), "Promotion includes advertising sale promotion, publicity and personal selling and refers to various methods of promoting the product, brand or company".

Menurut Dharmesta dan Irawan (2005:349), “Promosi adalah arus informasi atau persuasi satu arah yang dibuat untuk mengarahkan seseorang atau organisasi kepada tindakan yang menciptakan pertukaran dalam pemasaran”. Promosi merupakan kegiatan untuk memperkenalkan suatu produk kepada konsumen dan mempengaruhi konsumen agar tertarik untuk mengkonsumsinya atau membeli. Promosi merupakan suatu kegiatan di mana produk pertama kali dijual kepasaran dan mengadakan iklan dimedia-media yang bertujuan untuk masyarakat dapat mengetahui tentang produk yang sedang ditawarkan.

\section{Bauran Promosi (Promotion Mix)}

Saladin (2006:172) mengemukakan bahwa "Bauran promosi adalah kombinasi dari penjualan tatap muka, periklanan, promosi penjualan, publisiti, dan hubungan masyarakat yang membantu mencapai tujuan perusahaan". Menurut Swastha dan Irawan (2005:349), "Promotional Mix adalah kombinasi strategi yang paling baik dari variabel-variabel periklanan, personal selling dan alat promosi yang lain, yang semuanya direncanakan untuk mencapai tujuan program penjualan". Promotion mix merupakan kombinasi yang paling baik dari variabel-variabel periklanan (advertising), promosi penjualan (sales promotion), hubungan masyarakat (public relation), dan penjualan perseorangan (personal selling) yang semuanya direncanakan untuk membantu pencapaian tujuan program penjualan perusahaan.

\section{Inovasi Ekonomi}

Istilah inovasi dalam organisasi diperkenalkan oleh Schumpeter pada tahun 1934. Inovasi dipandang sebagai kreasi dan implementasi "kombinasi baru". Istilah kombinasi baru ini dapat merujuk produk, jasa, proses kerja, pasar, dan kebijakan sistem baru. Dalam inovasi dapat diciptakan nilai tambah, baik pada organisasi, pemegang saham, maupun masyarakat luas. Jadi, inovasi adalah memperkenalkan ide baru, barang baru, pelayanan baru, dan cara-cara baru yang lebih bermanfaat.

Menurut Rogers and Shoemaker (2003:85), "Perusahaan yang memiliki bentuk struktural organisasi yang terkoordinasi dengan baik dapat menunjang terciptanya inovasi yang lebih terarah pada pangsa pasar”. Menurut Porter (2005:98), “Innovation is the creation, exchange, evolution and application of new ideas into marketable goods, and services for the success of an organization, the vitality of a nation economy, and the andvancement of society as a whole". Menurut Kerin, Mahajan \& Varadarajan (2005:112), "A definition of innovation as a commercially valuable idea is common way to profit”. 
Berdasarkan beberapa defiisi tersebut di atas, maka dapat disimpulkan bahwa inovasi merupakan konsep yang membahas penerapan gagasan, produk atau proses yang baru. Menurut Rothberg (1981:4), inovasi memiliki berbagai ruang lingkup seperti inovasi ekonomi, inovasi teknologi, dan inovasi sosial. Inovasi ekonomi, yakni berhubungan dengan daya beli pemakai sehingga perlu dicari cara pembelian yang tidak membebankan para pemakai. Dengan cara pembelian cicilan memungkinkan pembeli dapat memiliki produk kebutuhannya yang sesuai dengan kemampuannya (Rothberg, 1981:4).

Definisi inovasi dalam ekonomi (Joseph Schumpeter, 1934:124), yaitu (1) Mengenalkan barang baru, di mana para pelanggan belum mengenalnya atau kualitas baru dari sebuah barang, (2) Mengenalkan metoda produksi baru yang dibutuhkan, (3) Membuka pasar baru, di mana perusahaan sejenis tidak memasukinya, baik pasar tersebut ada atau belum ada ketika perusahaan memasukinya, (4) Menguasai sumber bahan baku baru untuk industri barang., dan (5) Menjalankan organisasi baru seperti menciptakan monopoli, atau membuka monopoli perusahaan lain.

\section{Pemasaran}

Menurut Sartono (2000:130), “Dalam upaya menciptakan perluasan produk sangat ditentukan oleh beberapa faktor antara lain kemampuan manajemen dalam memasarkan produk, kinerja pemasaran produk, dan proses promosi produk”. Menurut Weston dan Bringham (2001:5), "Pertumbuhan dari banyaknya jumlah produk yang diperoleh dari tahun ke tahun yang semakin meningkat menunjukkan suatu kinerja pemasaran yang lebih baik”.

Menurut Weston dan Copeland (2000:237), “Menilai keberhasilan suatu organisasi bisnis ditunjukkan pada besaran dan ranking perusahaan dalam industri, tingkat pertumbuhan laba, Return On Investment (ROI), pangsa pasar, laju pertumbuhan deviden, reputasi kualitas produk, dan/ teknologi yang dipergunakan, dan kemampuan organisasi untuk bertahan dalam menghadapi konjungtur perekonomian”. Menurut Bleuel (2004:58), yang mendefinisikan kinerja pemasaran, yaitu "Marketing performance is the quality and quality of task accomplishment by an individual or group". Menurut Holme \& Watts (2005:167), "Marketing performance refers to how well an employee is fulfilling the requirement of the job".

\section{Kerangka Pemikiran}

Pengaruh orientasi pasar, program promosi, dan inovasi ekonomi secara individu dan bersama-sama terhadap pemasaran jasa kredit. Menurut sumber dari Ekobis Vol.7, No.1, Januari 2006, menyatakan bahwa:

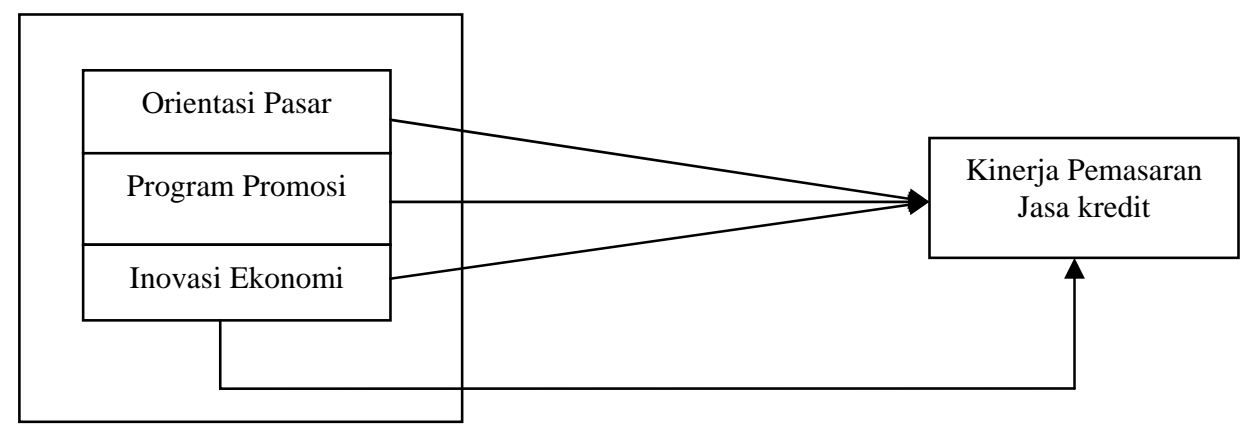

Gambar 2 Rerangka Pemikiran 
Pengaruh variabel X1 (Orientasi Pasar) terhadap variabel Y (Kinerja pemasaran):

Menurut Gregorius Chandra (2002:17), yang menguraikan bahwa karakteristik kunci orientasi pasar dapat dilihat dari:

“Orientasi pasar yang sukses bakal mengarah pada kinerja superior. Keberhasilan orientasi pasar ditunjang pula oleh kemampuan mengidentifikasi dan memperluas kapabilitas unik”. Komponen orientasi pasar:

1. Orientasi pelanggan

Mengutip pendapat Richard L.Daft (2003:80) mendefinisikan costumers sebagai:

"People and organization in the environment who can meet the needs and wants of customers both products and services from the organization".

Mengutip pendapat Kotler (2003:273) mendeskripsikan bahwa:

"A costumer centered company focus more on custumers development in formulating its strategeis".

Dari definisi di atas, dapat disimpulkan bahwa orientasi pelanggan bertujuan untuk dapat memenuhi kebutuhan dan keinginan pelanggan, baik produk maupun jasa.

2. Orientasi pesaing

Daft (2003:80) mendefinisikan sebagai berikut:

"Competitor is other organization in the same industry or type of business. That provides goods or service in the same set custumer".

Kotler (2003:273) mendeskripsikan sebagai berikut:

"Competitor orientation is one whose moves are basically deciated by competitors' action and reaction".

Dari definisi di atas, dapat disimpulkan bahwa orientasi pesaing adalah perusahaan yang tindakannya pada dasarnya dikendalikan oleh tindakan dan reaksi pesaing.

3. Koodinasi antar fungsi

Mengutip pendapat Liu dan Davies (2000), maka disajikan sebagai berikut:

"noted that fungsional coordination is a critical factor in retail business".

Dari teori di atas, dapat diartikan suatu usaha ke arah keselarasan kerja antara satu dengan yang lain sehingga diharapkan tidak terjadi kesimpangsiuran, ketidaktepatan serta dobel pekerjaan antara yang satu dengan yang lain sehingga pekerjaan dapat dilaksanakan secara efektif dan efisien.

\section{Pengaruh teori variabel X2 (Promosi) terhadap variabel Y (Pemasaran):}

Menurut Harper (2000:65), definisi dari promosi adalah sebagai berikut:

"promosi adalah suatu program terkendali dan terpadu dari metode komunikasi material perusahaan atau produk yang dapat memuaskan konsumen, mendorong penjualan serta memberi kontribusi pada kinerja laba perusahaan”.

Menurut Swastha $(2000 ; 245)$ mendefinisikan promosi sebagai:

"Promosi yang baik dapat menjadi tolak ukur perusahaan dalam menciptakan kinerja pemasaran yang maksimal”.

Pengaruh variabel X3 (Inovasi Ekonomi) terhadap variabel Y (Pemasaran):

Menurut Rogers and Shoemaker (2003:85) mendefinisikan inovasi sebagai berikut: "Perusahaan yang memiliki bentuk struktural organisasi yang terkoordinasi dengan baik dapat menunjang terciptanya inovasi yang lebih terarah pada pangsa pasar”.

Menurut Porter (2005:98) menguraikan definisi dari inovasi yaitu sebagai berikut:

"inovasi adalah penciptaan, pertukaran, evolusi dan penerapan ide-ide baru menjadi barang berharga dan pelayanan bagi keberhasilan organisasi, vitalitas ekonomi negara, dan kemajuan masyarakat secara keseluruhan”. 


\section{Operasionalisasi Variabel}

\begin{tabular}{|c|c|c|c|c|}
\hline Variabel & Definisi & Dimensi & Indikator & $\begin{array}{c}\text { Skala } \\
\text { Pengukuran }\end{array}$ \\
\hline $\begin{array}{l}\text { Orientasi } \\
\text { Pasar }\end{array}$ & $\begin{array}{l}\text { Orientasi pasar yang } \\
\text { sukses bakal mengarah } \\
\text { pada kinerja superior. }\end{array}$ & $\begin{array}{l}\text { - } \text { Orientasi } \\
\text { pelanggan } \\
\text { - Orientasi } \\
\text { pesaing } \\
\text { - Orientasi antar } \\
\text { fungsi }\end{array}$ & $\begin{array}{l}\text { - } \text { Mampu memenuhi } \\
\text { kebutuhan pelanggan. } \\
\text { - } \text { Mampu bereaksi } \\
\text { terhadap pesaing. } \\
\text { - Antar fungsi } \\
\text { berkoordinasi secara } \\
\text { efektif. }\end{array}$ & Skala Likert \\
\hline $\begin{array}{l}\text { Program } \\
\text { Promosi }\end{array}$ & $\begin{array}{l}\text { program yang mengacu } \\
\text { pada teknik-teknik untuk } \\
\text { mengkomunikasikan } \\
\text { informasi tentang produk } \\
\text { dan menjual produk. }\end{array}$ & $\begin{array}{l}\text { - Periklanan } \\
\text { - Direct marketing } \\
\text { - Sales promotion }\end{array}$ & $\begin{array}{l}\text { - Kualitas brosur dalam } \\
\text { - } \text { Menyebarkan info. } \\
\text { - } \quad \text { Mema tarik discount. } \\
\text { - }\end{array}$ & Skala Likert \\
\hline $\begin{array}{l}\text { Inovasi } \\
\text { Ekonomi }\end{array}$ & $\begin{array}{l}\text { cara pembelian cicilan } \\
\text { memungkinkan pembeli } \\
\text { dapat memiliki produk } \\
\text { kebutuhannya yang sesuai } \\
\text { dengan kemampuannya. }\end{array}$ & & $\begin{array}{l}\text { - Mengenalkan jasa } \\
\text { produk baru. } \\
\text { - Mengenalkan metode } \\
\text { cicilan. }\end{array}$ & Skala Likert \\
\hline $\begin{array}{l}\text { Kinerja } \\
\text { Pemasaran }\end{array}$ & $\begin{array}{l}\text { Hasil kerja yang dapat } \\
\text { dicapai oleh seseorang } \\
\text { atau sekelompok orang } \\
\text { dalam suatu organisasi, } \\
\text { sesuai dengan wewenang } \\
\text { dan tanggung jawab } \\
\text { masing-masing dalam } \\
\text { upaya mencapai tujuan } \\
\text { organisasi bersangkutan } \\
\text { secara legal }\end{array}$ & - Non keuangan & $\begin{array}{l}\text { - Kepuasan karyawan. } \\
\text { - Kualitas produk dan jasa. } \\
\text { - Reputasi perusahaan. }\end{array}$ & Skala Likert \\
\hline
\end{tabular}

Ho1 : Tidak terdapat pengaruh yang signifikan antara orientasi pasar terhadap pemasaran.

Ha1 : Terdapat pengaruh yang signifikan antara orientasi pasar terhadap pemasaran.

Ho2 : Tidak terdapat pengaruh yang signifikan antara promosi terhadap pemasaran.

Ha2 : Terdapat pengaruh yang signifikan antara promosi terhadap pemasaran.

Ho3 : Tidak terdapat pengaruh yang signifikan antara inovasi ekonomi terhadap pemasaran.

Ha3 : Terdapat pengaruh yang signifikan antara inovasi ekonomi terhadap pemasaran.

Ho4 : Tidak terdapat pengaruh yang signifikan antara orientasi pasar, program promosi, dan inovasi ekonomi terhadap pemasaran.

Ha4 : Terdapat pengaruh yang signifikan antara orientasi pasar, program promosi, dan inovasi ekonomi terhadap pemasaran

\section{HASIL DAN PEMBAHASAN}

Nilai koefisien korelasi antara Orientasi Pasar (X1) dengan Kinerja Pemasaran (Y) adalah 0,838, berarti menunjukkan hubungan yang kuat dan positif. Orientasi pasar berpengaruh secara signifikan terhadap kinerja pemasaran. Besarnya pengaruh variabel Orientasi Pasar (X1) terhadap Kinerja Pemasaran (Y) adalah 70.3\%, sedangkan sisanya 27,2\%, dipengaruhi oleh variabel lain. 
Berarti Orientasi pasar mempunyai pengaruh cukup besar terhadap kinerja pemasaran jasa kredit. Berarti kemampuan perusahaan untuk merespon pasar berdasarkan orientasi pelanggan, orientasi pesaing dan koordinasi antar fungsi mampu untuk mempengaruhi Pencapaian kinerja pemasaran melalui kepuasan karyawan, kualitas produk dan jasa, serta reputasi perusahaan.

Koefisien korelasi antara Program Promosi (X2) dengan Kinerja Pemasaran (Y) adalah 0,72, berarti menunjukkan hubungan yang positif dan kuat. Program promosi berpengaruh secara signifikan terhadap kinerja pemasaran. Pengaruh variabel Program Promosi (X2) terhadap Kinerja Pemasaran (Y) adalah 52,8\%, sedangkan sisanya 47,2\%, dipengaruhi oleh variabel lainnya. Promosi yang baik dapat menjadi tolak ukur perusahaan dalam menciptakan kinerja pemasaran yang maksimal seperti dengan penyebaran brosur, melakukan direct marketing via web dan dengan memberikan discount kepada para pelanggan. Keberhasilan dan pelaksaaan program promosi yang tepat akan berdampak positif dalam memperlancar penyebaran suatu produk atau jasa untuk mencapai pangsa pasar yang di targetkan perusahaan.

Nilai koefisien korelasi Inovasi Ekonomi (X3) dengan Kinerja Pemasaran (Y) adalah 0,859, menunjukkan hubungan yang positif dan kuat antara inovasi ekonomi dengan kinerja Pemasaran. Inovasi Ekonomi berpengaruh secara signifikan terhadap Kinerja Pemasaran. Besarnya pengaruh variabel Inovasi Ekonomi (X3) terhadap Kinerja Pemasaran (Y) adalah 73,9\%, sedangkan sisanya $26,1 \%$, dipengaruhi oleh variabel lainnya. Inovasi ekonomi dilakukan dengan pendekatan terhadap daya beli konsumen. Sales mengenalkan produk baru dengan cara memberikan metode cicilan kepada konsumen yang mempunyai pengaruh besar terhadap Pemasaran jasa kredit. Dengan mengenalkan metode cicilan yang variatif dan sesuai dengan kemampuan konsumen serta menawarkan asuransi kecelakaan, sales mampu mencapai kinerja pemasaran yakni tidak hanya berdampak pada penjualan jasa dan pencapaian target karyawan saja tetapi juga reputasi Perusahaan.

Terdapat pengaruh yang signifikan antara orientasi pasar, program promosi, inovasi ekonomi terhadap pemasaran. $74,1 \%$ kinerja pemasaran dipengaruhi oleh variabel orientasi pasar, program promosi, inovasi ekonomi. Sementara sisanya dipengaruhi oleh variabel-variabel lain. Untuk menentukan variasi 3 variabel terhadap kinerja pemasaran dihasilkan persamaan regresi, yakni $\mathbf{Y}=$ 0,364 - 0,057 X1 + 0,085 X2 + 0,537 X3. Hal ini menunjukkan bahwa perencanaan selanjutnya bila berdasarkan variasi yang terjadi bahwa kinerja marketing akan meningkat bila aktivitas orientasi pasar dikurangi sedangkan program promosi dan inovasi ekonomi perlu ditingkatkan. Perusahaan perlu memperhatikan orientasi pasar yang dilakukan selama ini dan mengevaluasi dampaknya sehingga apabila dilaksanakan bersamaan dengan program promosi dan inovasi ekonomi dapat membantu meningkatkan kinerja pemasaran jasa kredit.

\section{SIMPULAN}

Dari hasil pengolahan data dan analisa pembahasan maka dapat diambil beberapa simpulan, antara lain (1) Orientasi pasar yang dilakukan ternyata berperan mempengaruhi sales dalam pemasaran. Untuk itu diperlukan aktivitas yang selektif dalam memantau orientasi pelanggan, orientasi pesaing dan koordinasi antar fungsi sehingga mampu meningkatkan kinerja marketing, (2) Promosi berperan dalam mempengaruhi sales dalam pemasaran. Brosur, discount, direct marketing perlu diprogramkan kembali dengan cara melakukan perbaikan atau menambah kegiatan program promosi yang lebih intensif di berbagai media baik cetak maupun elektronik yang lebih mudah diingat, selain promosi iklan di berbagai media, kiranya juga meningkatkan kinerja pemasaran dari penjualan perorangan, karena penjualan peroranganlah yang membangun hubungan langsung dengan konsumen, promosi penjualan pun harus tetap ditingkatkan agar masyarakat semakin mengenal produk secara langsung melalui pameran-pameran maupun kontes-kontes, (3) Inovasi ekonomi berperan 
mempengaruhi sales dalam pemasaran. Inovasi ekonomi dapat lebih dipertahankan dan dilakukan evaluasi berkala disesuaikan dengan tingkat daya beli masyarakat, (4) Kegiatan Orientasi pasar bila dilakukan secara bersamaan dengan variable lain perlu untuk dikurangi sehingga perusahaan tidak hanya terpaku pada orientasi pasar tetapi juga penting memperhatikan sales untuk mencapai targetnya masing-masing melalui variasi program promosi dan inovasi ekonomi karena optimalisasi dua kegiatan ini mampu berdampak positip pada peningkatan kinerja pemasaran.

\section{DAFTAR PUSTAKA}

Akdon. (2006), Strategik Managemen, Yogyakarta.

Best, R., Valence, G.de., and Langston, C. (2003). Workplace strategies and facilities management building in value, $1^{\text {st }}$ publisher, Elsevier Science Ltd, All Right Reserved.

Beugree, C.D. (2005) Managing fairness in organizatition: Applying justice concepts in organization, Greenwood Publishing group.

Bleuel, W. (2004). Customer satisfaction, $3^{\text {rd }}$ ed., Scantron A Harland Company.

Boyd, W.M.L. (2004). Marketing strategic, a decision focused, $4^{\text {th }}$ ed., me Graw hill Irwin.

Brigham, J,C. (2005). Social psychology, New York: Harper Collins Publisher.

Drucker, P. (2002). Management: Task, responsibilities, and practices, New York Harper \& Row.

Gallo, T.E. (2005). Strategic information management panning. Englewood Cliffs, New Jersey: Prentice Hall.

Ghozali, I. (2001). Aplikasi analisis mutivariate dengan program SPSS, edisi kedua, Semarang: Badan Penerbit Universitas Diponegoro.

Ghozali, I. (2005). Aplikasi analisis multivariate dengan program SPSS, edisi ketiga, Semarang: Badan Penerbit Universitas Diponegoro.

Holme, L., and Watts, R. (2005). Marketing good business sense, The Word Business Council for Sustainable Development in its Publication.

Indriantoro, N., dan Suparmono, B. (2002). Metodologi penelitian bisnis untuk akuntansi dan manajemen, edisi pertama, cetakan kedua, Yogyakarta: BPEE.

Kenin, R.A., Mahajon, V., and Varadarajon, P.R. (2005). Contemporary: Perpective on strategic planning, Allyen and Boston.

Kotler, P. (2003). Marketing management, $11^{\text {th }}$ ed., Internasional Edition, New Jersey: Prentice Hall Inc.

Kotler, P., and Amstrong, G. (2005). Marketing management, $10^{\text {th }}$ ed., New Jersey: Person Education Internasional Prentice Hall. 
Kotler, P., and Keller, K.L. (2006). Marketing management, $12^{\text {th }}$ ed., New Jersey: Person Education International Prentice Hall.

Lamb, C.W.Jr., Hair, Joseph F.Jr., and McDaniel, C. (2004). Essential of marketing, $7^{\text {th }}$ ed., South Western Publicing Collage.

Levint, The Othare. (2005). Marketing imagination, International Edition, NewYork: Free Press.

Mc Kenna, R. (2004). Relationship marketing, Reading Mass Adison Weshley Publicing Co.

Murray, H.A. (2005). Expleration in personality, New York: Oxford University Tress.

Naisbitt, Y. (2004). Megatrens: Ten new direction tranforming orlines, New York: Warner Books.

Nitisemo, A. (2004). Manajemen personalia: Manajemen sumber daya manusia, Jakarta: Galia Indonesia.

Porter, M.E. (2005). Competitive strategy: Techniques for analysing industries and competitors, New York: Free Press.

Pramono, S., dan Waridin. (2006). Pengaruh faktor orientasi pasar, promosi dan inovasi terhadap kinerja pemasaran kredit (studi kasus pada Bank BRI wilayah Jawa tengah), Ekobis, Vol.7, No.1, Januari, 33-40.

Purnawarman, T. (2001). Strategi pemasaran dan pengendalian mutu produk, Jakarta: PT Raja Grasindo Persada.

Santoso, S., dan Taipetono, S. (2001). Riset pemasaran: Konsep dan aplikasi dengan SPSS, Alex Media Komputindo.

Sugiono. (2004). Metode penelitian bisnis, cetakan ketujuh, Bandung: Alfabella.

Sschissmaen, L., Kanuk, G., dan Leslie, L. (2004). Perilaku konsumen, edisi ketujuh, edisi Indonesia.

Thomas, E.G. (2003). Strategy information management planning, Englewood Cliffs, and J. Prentice Hall. 